\title{
Taxonomic and functional diversity of birds in a rural landscape of high Andean forest, Colombia
}

\author{
Lina P. Sarmiento-Garavitoำ, Juan S. García-Monroy ${ }^{1}$, Juan E. Carvajal-Cogollo ${ }^{1}$ \\ 1 Grupo de Investigación Biodiversidad and Conservación, Museo de Historia Natural Luis Gonzalo \\ Andrade Natural, Facultad de Ciencias, Universidad Pedagógica y Tecnológica de Colombia, Address \\ Avenida Central del Norte 39-115, 150003 Tunja, Boyacá, Colombia
}

Corresponding author: Juan E. Carvajal-Cogollo (juancarvajalc@gmail.com)

Academiceditor:A.M.Leal-Zanchet |Received 18March2021 |Accepted2February2022|Published 17February2022

Citation: Sarmiento-Garavito LP, García-Monroy JS, Carvajal-Cogollo JE (2022) Taxonomic and functional diversity of birds in a rural landscape of high Andean forest, Colombia. Neotropical Biology and Conservation 17(1): 39-57. https://doi.org/10.3897/neotropical.17.e66096

\begin{abstract}
We evaluated the taxonomic and functional diversity of birds in a rural landscape in the north-eastern Andes of Colombia. We carried out seven field trips and used transects of $300 \mathrm{~m}$, separated from each other by $500 \mathrm{~m}$ in the dominant plant cover of the rural landscape. We measured alpha $(\alpha)$ and beta $(\beta)$ diversity at both the taxonomic and functional levels. We registered 10 orders, 21 families, 56 genera and 63 species of birds. In wooded pasture, we recorded 55 species and a relative abundance of $66 \%$ and 44 and 34\% for an Andean forest fragment. The species that contributed the most to the dissimilarity between the covers were Zonotrichia capensis, Turdus fuscater, Mecocerculus leucophrys, Atlapetes latinuchus and Crotophaga ani. We identified nine functional types, where G1 was made up of small species with anissodactyl and pamprodactyl legs that were insectivorous, frugivorous and nectarivorous as the best represented. The FEve and FDiv were 0.51 and 0.74 , respectively in the Andean forest fragment plant cover and, for the wooded pasture, the FEve was 0.45 and the FDiv was 0.81 . Both cover types contributed to the diversity of the rural landscape and the dynamics that existed between them formed a complementary factor that favoured the taxonomic and functional richness of the characterised rural landscape.
\end{abstract}

\section{Keywords}

Colombian Andes, countryside, functional traits, species composition, species richness, transformed landscape 


\section{Introduction}

The transformation of landscapes by the loss and fragmentation of land-cover types results in a mosaic of native plant cover, surrounded by extensive areas of anthropogenic cover types (Collinge 2009; IPBES 2019). Agriculture and pastures, destined for livestock, form a large part of these new land covers and their unplanned extension does not allow sustainable use to be recognised as one of the current threats to biodiversity, both at the taxonomic scale (richness, composition and abundance) and at the functional level (diversity of functional traits) (Tscharntke et al. 2012; Freedman 2014). The extension of agricultural activities and livestock affect biological communities in their structure and composition and leads to functional and ecological destabilisation of natural systems (Bilenca et al. 2017). This conglomerate of effects on arable land fractions without buildings, but not containing agricultural land, crops, plantations and managed forests, as well as remnants of native vegetation, is what has been defined as rural landscape (Daily et al. 2001; Ranganathan and Daily 2008).

Rural landscapes favour positive and negative responses from biodiversity, depending on the intensity of habitat loss or fragmentation and the study group (Lawton et al. 1998; Newbold et al. 2013). For flocks of birds, studies show that they respond positively to habitat fragmentation (Villard et al. 1999; Lampila et al. 2005). In this way, when evaluating the responses of taxonomic diversity (species richness, composition and abundance) and functional variety, we understand the connection between species and how these are integrated into ecosystems (Villéger et al. 2008; Cadotte et al. 2011; López-Ordoñez et al. 2015). At the taxonomic level, the evaluation of specific diversity (alpha) through the analysis of species richness, relative abundance (structure) and species composition added to the quantification of diversity functional traits of species provides new and complementary information for the conservation of species in rural landscapes (Oldeland et al. 2010). This fact becomes relevant if we consider the changes that species undergo at the level of behavioural and functional attributes with habitat disturbance, as seen in the Andes of Colombia, where severe transformation patterns linked to human occupation have been documented (Cavelier and Etter 1995; MoranteFilho et al. 2016).

Rural landscapes modify positive and negative responses from biodiversity, depending on the intensity of the loss and/or fragmentation of the habitats and the study group (Lawton et al. 1998; Newbold et al. 2013). For many bird flocks, there are studies that demonstrate positive responses to habitat fragmentation (Villard et al. 1999; Lampila et al. 2005). In this way, when evaluating the responses of diversity from the taxonomic and functional dimensions, it allows us to understand the connection between species and the functioning of ecosystems (Cadotte et al. 2011; López-Ordoñez et al. 2015). At the taxonomic level, the evaluation of specific diversity (alpha), through species richness analysis, relative abundance (structure) and species composition added to the quantification of the diversity of functional 
features of species (functional dimension) provides new and complementary information for the conservation of species in rural landscapes, but especially for those that have suffered severe patterns of transformation linked to human occupation of regions like the Andean cordillera of Colombia (Cavelier and Etter 1995; Oldeland et al. 2010; Morante-Filho et al. 2016).

The landscapes of the Andean region of Colombia are the most diverse on the planet, with species that have limited ranges of distribution generating elements where the alpha and beta diversity of various taxonomic groups, such as birds, are highly expressed (Carvajal-Castro et al. 2019). Birds have been widely used as a biological model, thanks to their biological and ecological qualities (Veríssimo et al. 2009; Larsen et al. 2012); and the evaluation of different parameters of their assemblages can be used as inputs for the establishment of areas of importance or conservation strategies in each area (Westgate et al. 2014). In addition, birds have wide distribution, high taxonomic diversity and functional levels and an ability to attract attention and arouse the fascination of people making them a model for study (Veríssimo et al. 2009; Ikin et al. 2016).

We evaluated the taxonomic and functional diversity of birds in wooded grasslands and forest fragments in a rural landscape in the Colombian Andes. We started from the premise that grasslands with trees with a simple plant structure would have lower values of alpha diversity, both taxonomic and functional, in relation to forest fragments, whose plant structure is complex and stratified and provides greater availability of resources for the species. Similarly, beta diversity between assemblages will be structured by high turnover in species composition.

\section{Materials and methods}

\section{Study area}

The research was carried out in an Andean rural landscape of the Eastern Cordillera of Colombia $\left(5^{\circ} 42^{\prime} 20^{\prime \prime} \mathrm{N}, 73^{\circ} 30^{\prime} 35^{\prime \prime} \mathrm{W}\right)$, at $2583 \mathrm{~m}$ a.s.l., in the Department of Boyacá. The study area has temperatures between $11^{\circ} \mathrm{C}$ and $15^{\circ} \mathrm{C}$, relative humidity between $80 \%$ and $82 \%$ and a mean annual rainfall between $1000 \mathrm{~mm}$ and $1900 \mathrm{~mm}$ with two rainfall peaks per year, the first between March and April and the second between October and November (Galindo 2000).

The study area (Fig. 1A-D) was a landscape dominated by two types of cover, namely Andean forest fragments and wooded grasslands. The forest fragments are remnants of the original vegetation, composed of Quercus humboldtii or oak, with arborescent elements that have colonised the spaces made available by logging, giving space to Pinus patula plantations, Acacias melanoxylon and Acacia decurrens (Rangel-Ch et al. 1997). The second dominant cover of wooded grasslands are defined as open areas with isolated Melastomataceae and Clusiaceae trees, with herbaceous and shrub elements $(70 \%)$, dedicated to cattle grazing (Rangel-Ch. et al. 1997). 


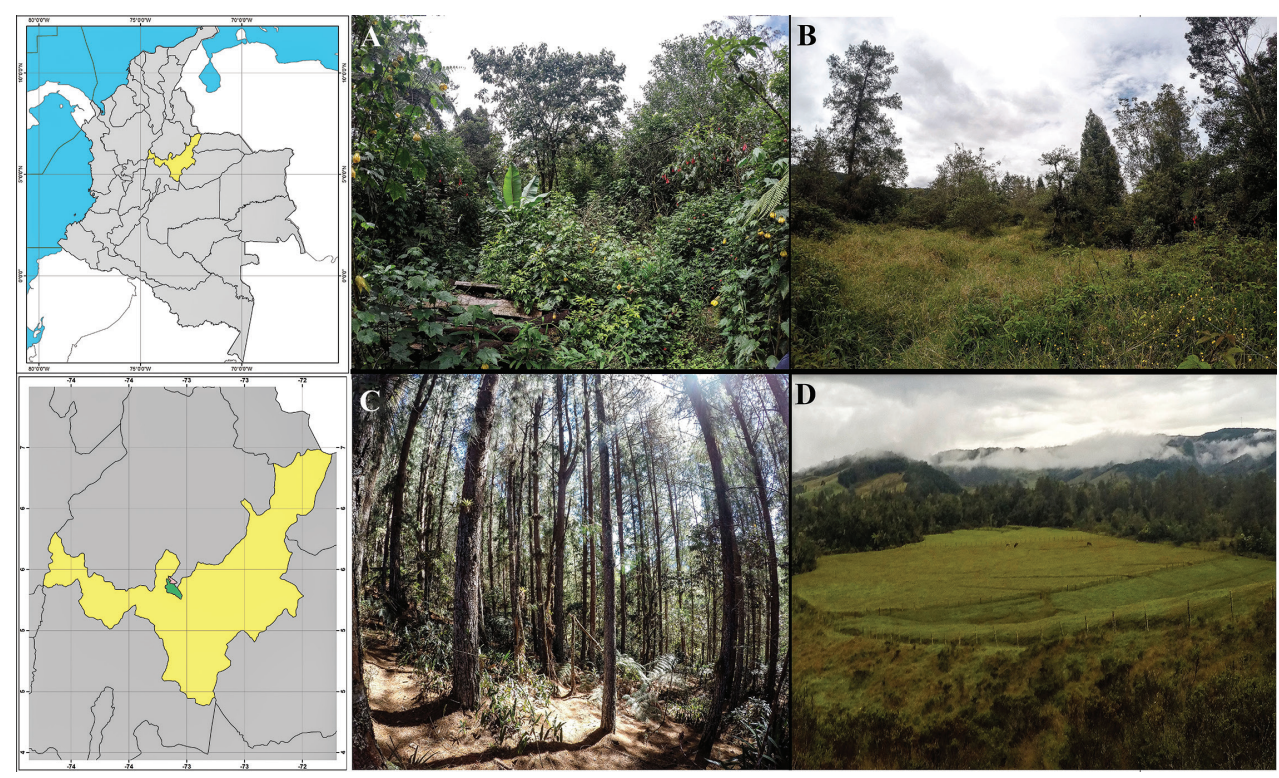

Figure 1. Location of the study area, an Andean rural landscape of the Eastern Cordillera of Colombia. The sampled landscape units are highlighted A, B wooded pasture C, D Andean Forest.

\section{Research design and sampling}

We established transects in an Andean forest fragment of 17.57 ha and a wooded pasture of $12.13 \mathrm{ha}$, both at an altitude of $2527 \mathrm{~m}$ above sea level. For each of the sampled covers (fragment of Andean forest and wooded pasture), we carried out two free travel transects with a length of $300 \mathrm{~m}$ each, separated from each other by 500 linear $\mathrm{m}$, a distance documented as optimal for data collection in linear transects and that for the study area guaranteed the independence of samples, due to the topography of the area with steep slopes that spatially increased the real distance across the land surface (Gale et al. 2009). Each transect was replicated in space and time and represented the minimum sampling unit. The order of sampling of each transect was carried out randomly to eliminate the correlation between the observations and avoid overestimations in the richness and abundance of the species (Ralph et al. 1996). In each transect, all bird species that were visually detected within an unlimited radius, for 10 minutes in the morning sampling and eight minutes in the evening sampling, for a total of 18 minutes per point/day (Howe et al. 1997; Leach et al. 2016).

We carried out seven field trips between June and December 2017. During this period, we registered the birds for the climatic seasons that characterise the area and a migration peak, to obtain real estimates of alpha diversity. During each field trip, we walked a daily transect two times, one in the morning from 5:30 h to 10:30 h and another in the mid- to late afternoon between 15:00 $\mathrm{h}$ and 17:30 $\mathrm{h}$. We rotated these schedules throughout the field trips to obtain records of most species, given their 
activity peaks (Ralph et al. 1996). For bird watching, we used $10 \times 50$ binoculars and reflex cameras with a $150-600 \mathrm{~mm}$ super telephoto lens and a $75-300 \mathrm{~mm}$ lens. The sampling effort was 420 hours/person.

For recording information, formats were used daily during each field trip. In these formats, we recorded the data of the coordinates of the place of each observation, the altitude, the date and the time of the sighting, the foraging stratum and the social behaviour (López-Ordoñez et al. 2015). In addition, the number of individuals observed (detections) made up the basic input for the analysis of alpha and beta diversity.

Taxonomic determination was carried out with specialised pictorial keys for neotropical and Colombian birds (Restall et al. 2007; Ridgely and Tudor 2009; McMullan and Donegan 2014). The taxonomic arrangement followed Remsen et al. (2020).

\section{Analysis of data}

We evaluated the alpha diversity ( $\alpha$ ) of each vegetation type (cover type) from data of relative richness and abundance. We used the sample's completeness method (Chao and Jost 2012) that measures the proportion represented by the individuals of each species in the sample with respect to the total number of individuals with which the expected species could be quantified through accumulation curves. Sampling coverages were evaluated through accumulation curves (rarefaction and extrapolation) and with the Hill numbers and the evaluation of $\mathrm{q}=0$ that measured the total species richness (true diversity), the $\mathrm{q}=1$ that expressed the exponential of the Shannon Entropy Index and q = 2, corresponding to the inverse of the Simpson Index (Chao et al. 2014). For each analysis, we used the procedure of Chao and Jost (2012) in the iNEXT programme (Hsieh et al. 2013). In addition, we applied nonparametric estimators of Chao 1 and bootstrap for a better approach to the structure of the bird assemblage (Chao and Lo 1994), since there were species that were represented by few individuals. We quantified the values of singletons and doubletons and of any unique and duplicate samples using the programme EstimateS version 9.0 (Colwell et al. 2019).

The structure of the bird assemblage, expressed by the relative abundance of the species, was obtained from the division of the number of individuals counted for each species and the total numbers per cover type taken as a percentage (Pettingill 1985; Issa 2019). We applied analysis of similarity of the abundance matrix (ANOSIM) to determine if there were differences in the composition of birds between cover types and a SIMPER analysis to identify the taxa that contributed to the differentiation or similarity between the groups through the percentages of contribution (PC) and accumulation (AC) of the detections in each of the vegetation cover types (Clarke 1993). Beta diversity $(\beta)$ was analysed by means of the turnover of species between the two vegetation cover types with the complementarity index. Exclusive and shared species between both cover types were also identified (Colwell and Coddington 1994). 
For the functional diversity analyses, we considered four ethological functional traits related to the ecological role of nutrient and energy flow within the ecosystem (Stotz et al. 1996; López-Ordoñez et al. 2015): 1. Type of diet (carnivore, scavenger, folivore, frugivore, granivore, insectivore, nectarivore) (Stotz et al. 1996; Wilman et al. 2014); 2. Feeding strategy (catcher, forager, robber) (López-Ordoñez et al. 2015), 3. Foraging stratum (arboreal, shrub, herbaceous and soil) (Rangel-Ch and LozanoC 1986); and 4. Social behaviour (mixed flock, monospecific flock and solitary). Furthermore, we took into account four morphometric traits, related to the selection of foraging sites and seed dispersal (Sekercioglu 2006): 1. Type of legs (anissodactyls, pamprodactyls, sydactyls, totipalmos, zygodactyls); 2. Beak shape (tall and compressed, conical, short and robust, recurved, curved, fine and pointed, hooked, slightly curved, pointed, straight, straight and fine, straight and pointed) and 3. Body size (large, medium, small) (Herrel et al. 2005; López-Ordoñez et al. 2015). The values of the functional traits were obtained in the field and supplemented by secondary information.

To quantify functional diversity, we performed a cluster analysis to identify functional types of birds in each of the sampled habitats (Petchey and Gaston 2002; Casanoves et al. 2011). We also calculated two multidimensional-multifunctional indices, functional equity (FEve) and functional dispersion (FDis) (Mouillot et al. 2005; Laliberté and Legendre 2010). For these analyses, we used the statistical packages infoStat and FDiversity that connects to the statistical programme $\mathrm{R}$ with an interface written in Delphi with DCOM-R (Di Rienzo 2009; Casanoves et al. 2011).

\section{Results}

\section{Richness and composition of bird assemblages}

We registered 10 orders, 21 families, 56 genera and 63 species of birds (Table 1). In the wooded pasture, the richness was 55 species, followed by the Andean forest fragment with 44 species. The families with the highest abundances were Passerellidae with 282 individuals, followed by Parulidae with 185 and Trochilidae with 179. The genera with the highest number of individuals were Atlapetes (183), Myioborus (103) and Coeligena (103). In the Andean forest fragment, the two best represented families were Trochilidae with eight genera and Passerellidae with four and, in the wooded pasture, they were Trochilidae with seven genera and Tyrannidae with five.

We obtained a high proportion of avian species richness from the two cover types. The percentage of representativeness was $94.39 \%$ and $94.38 \%$, for the wooded pastureland and the Andean forest fragment, respectively (Fig. 2A-C).

\section{Structure of the bird assemblage}

In the wooded pasture, we obtained a relative abundance of $66 \%$ (838 individuals), with nine species represented by only one individual and 10 species with two 
Table 1. Composition and richness of birds and their respective absolute and relative abundances in an Andean rural landscape of the Eastern Cordillera of Colombia. The five most abundant species for each cover are highlighted in bold.

\begin{tabular}{|c|c|c|c|c|c|c|c|}
\hline \multirow[t]{2}{*}{ Taxon name } & \multirow[t]{2}{*}{ English name } & \multirow[t]{2}{*}{ Code } & \multicolumn{2}{|c|}{ Absolute Abundance (AA) } & \multicolumn{2}{|c|}{ Relative abundance (RA\%) } & \multirow{2}{*}{$\begin{array}{c}\text { Functional } \\
\text { group }\end{array}$} \\
\hline & & & $\begin{array}{l}\text { Fragments of } \\
\text { Andean forest }\end{array}$ & $\begin{array}{l}\text { Wooded } \\
\text { pasture }\end{array}$ & $\begin{array}{c}\text { Fragments of } \\
\text { Andean forest }\end{array}$ & $\begin{array}{l}\text { Wooded } \\
\text { pasture }\end{array}$ & \\
\hline \multicolumn{8}{|l|}{ Galliformes } \\
\hline \multicolumn{8}{|l|}{ Cracidae } \\
\hline Penelope montagnii & Andean Guan & Pem & 3 & 0 & 0.718 & 0 & G9 \\
\hline \multicolumn{8}{|l|}{ Columbiformes } \\
\hline \multicolumn{8}{|l|}{ Columbidae } \\
\hline Patagioenas fasciata & Band-tailed Pigeon. & Paf & 0 & 15 & 0 & 1.789 & G4 \\
\hline Zenaida auriculata & Eared Dove & Zea & 0 & 3 & 0 & 0.358 & G4 \\
\hline \multicolumn{8}{|l|}{ Cuculiformes } \\
\hline \multicolumn{8}{|l|}{ Cuculidae } \\
\hline Crotophaga ani & Smooth-billed Ani & Cra & 0 & 33 & 0 & 3.938 & G8 \\
\hline Piaya cayana & Squirrel Cuckoo & Pic & 4 & 0 & 0.957 & 0 & G8 \\
\hline Coccyzus americanus & Yellow-billed Cuckoo & Coa & 2 & 5 & 0.478 & 0.597 & G8 \\
\hline \multicolumn{8}{|l|}{ Apodiformes } \\
\hline \multicolumn{8}{|l|}{ Trochilidae } \\
\hline Adelomyia melanogenys & $\begin{array}{l}\text { Speckled Humming- } \\
\text { bird }\end{array}$ & Adm & 18 & 6 & 4.307 & 0.716 & G1 \\
\hline Chaetocercus heliodor & Gorgeted Woodstar & Chh & 1 & 1 & 0.240 & 0.120 & G1 \\
\hline Chaetocercus mulsant & White-bellied Woodstar & $\mathrm{Chm}$ & 0 & 8 & 0 & 0.955 & G1 \\
\hline Campylopterus falcatus & Lazuline Sabrewing & Caf & 10 & 0 & 2.393 & 0 & G1 \\
\hline Chlorostilbon poortmani & Short-tailed Emerald & Chp & 1 & 1 & 0.240 & 0.120 & G1 \\
\hline Coeligena prunellei & Black Inca & Cop & 30 & 40 & 7.177 & 4.773 & G1 \\
\hline Colibri coruscans & Sparkling violet-ear & $\mathrm{Coc}$ & 2 & 4 & 0.479 & 0.478 & G1 \\
\hline Colibri cyanotus & Lesser Violetear & Coy & 18 & 14 & 4.307 & 1.671 & G1 \\
\hline $\begin{array}{l}\text { Heliangelus } \\
\text { amethysticollis }\end{array}$ & $\begin{array}{l}\text { Amethyst-throated } \\
\text { Sunangel. }\end{array}$ & Hea & 11 & 2 & 2.632 & 0.239 & G1 \\
\hline Metallura tyrianthina & Tyrian Metaltail. & Met & 3 & 9 & 0.718 & 1.074 & G1 \\
\hline \multicolumn{8}{|l|}{ Pelecaniformes } \\
\hline \multicolumn{8}{|l|}{ Ardeidae } \\
\hline Ardea alba & Great White Egret & Ara & 0 & 1 & 0 & 0.120 & G9 \\
\hline \multicolumn{8}{|l|}{ Cathartiformes } \\
\hline \multicolumn{8}{|l|}{ Cathartidae } \\
\hline Coragyps atratus & Black Vulture & Cga & 2 & 2 & 0.479 & 0.239 & G9 \\
\hline Cathartes aura & Turkey Vulture & $\mathrm{Caa}$ & 0 & 2 & 0 & 0.239 & G9 \\
\hline \multicolumn{8}{|l|}{ Accipitriformes } \\
\hline \multicolumn{8}{|l|}{ Accipitridae } \\
\hline Rupornis magnirostris & Roadside hawk. & Rum & 3 & 7 & 0.718 & 0.836 & G4 \\
\hline \multicolumn{8}{|l|}{ Coraciiformes } \\
\hline Alcedinidae & & & & & & & \\
\hline Megaceryle torquate & Ringed Kingfisher & Meq & 0 & 2 & 0 & 0.239 & G9 \\
\hline Piciformes & & & & & & & \\
\hline Picidae & & & & & & & \\
\hline Colaptes rivolii & $\begin{array}{l}\text { Crimson-mantled } \\
\text { Woodpeck-er. }\end{array}$ & Cor & 6 & 1 & 1.436 & 0.120 & G7 \\
\hline Melanerpes formicivorus & Acorn Woodpeck-er & Mef & 0 & 2 & 0 & 0.239 & G7 \\
\hline Ramphastidae & & & & & & & \\
\hline $\begin{array}{l}\text { Aulacorhynchus } \\
\text { prasinus }\end{array}$ & Emerald Toucanet & Aup & 0 & 2 & 0 & 0.239 & G6 \\
\hline Passeriformes & & & & & & & \\
\hline Passerellidae & & & & & & & \\
\hline Arremon brunneinucha & $\begin{array}{l}\text { Chestnut-capped } \\
\text { Brush-finch }\end{array}$ & Arb & 4 & 0 & 0.957 & 0 & G3 \\
\hline
\end{tabular}




\begin{tabular}{|c|c|c|c|c|c|c|c|}
\hline \multirow[t]{2}{*}{ Taxon name } & \multirow[t]{2}{*}{ English name } & \multirow[t]{2}{*}{ Code } & \multicolumn{2}{|c|}{ Absolute Abundance (AA) } & \multicolumn{2}{|c|}{ Relative abundance (RA\%) } & \multirow{2}{*}{$\begin{array}{c}\text { Functional } \\
\text { group }\end{array}$} \\
\hline & & & $\begin{array}{l}\text { Fragments of } \\
\text { Andean forest }\end{array}$ & $\begin{array}{l}\text { Wooded } \\
\text { pasture }\end{array}$ & $\begin{array}{l}\text { Fragments of } \\
\text { Andean forest }\end{array}$ & $\begin{array}{l}\text { Wooded } \\
\text { pasture }\end{array}$ & \\
\hline Atlapetes albofrenatus & $\begin{array}{l}\text { Moustached Brush- } \\
\text { finch }\end{array}$ & Ata & 26 & 54 & 6.221 & 6.444 & G2 \\
\hline Atlapetes latinuchus & $\begin{array}{l}\text { Yellow-breasted Brush- } \\
\text { finch }\end{array}$ & Atl & 32 & 71 & 7.656 & 8.473 & G2 \\
\hline $\begin{array}{l}\text { Chlorospingus } \\
\text { canigularis }\end{array}$ & $\begin{array}{l}\text { Ashy-throated Chloro- } \\
\text { spingus }\end{array}$ & Chc & 13 & 5 & 3.111 & 0.597 & G2 \\
\hline $\begin{array}{l}\text { Chlorospingus } \\
\text { flavopectus }\end{array}$ & $\begin{array}{l}\text { Common Chloro- } \\
\text { spingus }\end{array}$ & Chf & 17 & 2 & 4.067 & 0.239 & G2 \\
\hline Zonotrichia capensis & $\begin{array}{l}\text { Rufous-collared } \\
\text { Sparrow }\end{array}$ & Zoc & 2 & 56 & 0.479 & 6.683 & G2 \\
\hline \multicolumn{8}{|l|}{ Turdidae } \\
\hline Catharus ustulatus & Swainson's Thrush & Cau & 0 & 4 & 0 & 0.478 & G3 \\
\hline Turdus ignobilis & Black-billed Thrush & Tui & 0 & 3 & 0 & 0.358 & G3 \\
\hline Turdus fuscater & Great Thrush & Tuf & 8 & 65 & 1.914 & 7.757 & G4 \\
\hline \multicolumn{8}{|l|}{ Thraupidae } \\
\hline Diglossa albilatera & $\begin{array}{l}\text { White-sided Flower- } \\
\text { piercer }\end{array}$ & Dia & 18 & 31 & 4.307 & 3.701 & G4 \\
\hline Diglossa caerulescens & Bluish Flower-piercer & $\mathrm{Dgc}$ & 0 & 1 & 0 & 0.120 & G3 \\
\hline Diglossa cyanea & Masked Flower-piercer & Dic & 5 & 8 & 1.197 & 0.955 & G1 \\
\hline Stilpnia heinei & Black-Capped Tanager & Tah & 4 & 7 & 0.957 & 0.836 & G2 \\
\hline $\begin{array}{l}\text { Sporathraupis } \\
\text { cyanocephala }\end{array}$ & Blue-capped Tanager & $\mathrm{Spc}$ & 13 & 35 & 3.111 & 4.177 & G1 \\
\hline \multicolumn{8}{|l|}{ Tyrannidae } \\
\hline Elaenia frantzii & Mountain Elaenia & Elf & 2 & 18 & 0.479 & 2.148 & G1 \\
\hline $\begin{array}{l}\text { Mecocerculus } \\
\text { leucophrys }\end{array}$ & $\begin{array}{l}\text { White-banded } \\
\text { Tyrannulet }\end{array}$ & Mel & 11 & 51 & 2.632 & 6.086 & G1 \\
\hline Pitangus sulphuratus & Great Kiskadee & Pis & 0 & 6 & 0 & 0.716 & G4 \\
\hline $\begin{array}{l}\text { Pyrrhomyias } \\
\text { cinnamomeus }\end{array}$ & Cinnamon Flycatcher & Pyc & 1 & 0 & 0.240 & 0 & G3 \\
\hline Tyrannus melancholicus & Tropical Kingbird & Tym & 0 & 10 & 0 & 1.194 & G1 \\
\hline Zimmerius chrysops & $\begin{array}{l}\text { Golden-faced } \\
\text { Tyrannulet }\end{array}$ & Zic & 3 & 5 & 0.718 & 0.597 & G1 \\
\hline \multicolumn{8}{|l|}{ Troglodytidae } \\
\hline Troglodytes aedon & House Wren & Tra & 0 & 13 & 0 & 1.552 & G1 \\
\hline Henicorhina leucophrys & $\begin{array}{l}\text { Grey-breasted Wood } \\
\text { Wren }\end{array}$ & $\mathrm{Hel}$ & 9 & 10 & 2.154 & 1.194 & G1 \\
\hline $\begin{array}{l}\text { Pheugopedius mystacalis } \\
\text { Icteridae }\end{array}$ & Whiskered Wren & $\mathrm{Phm}$ & 1 & 0 & 0.240 & 0 & G3 \\
\hline Icterus chrysater & Yellow-backed Oriole & Icc & 26 & 44 & 6.221 & 5.251 & G1 \\
\hline $\begin{array}{l}\text { Sturnella magna } \\
\text { Furnariidae }\end{array}$ & Eastern Meadow-lark & Stm & 0 & 6 & 0 & 0.716 & G4 \\
\hline $\begin{array}{l}\text { Lepidocolaptes } \\
\text { lacrymiger }\end{array}$ & $\begin{array}{l}\text { Montane Wood- } \\
\text { creeper. }\end{array}$ & Lel & 2 & 0 & 0.479 & 0 & G5 \\
\hline Synallaxis azarae & Azara's Spinetail & Sya & 12 & 44 & 2.871 & 5.251 & G1 \\
\hline $\begin{array}{l}\text { Xenops rutilans } \\
\text { Parulidae }\end{array}$ & Streaked Xenops & Xer & 2 & 1 & 0.479 & 0.120 & G5 \\
\hline Mniotilta varia & $\begin{array}{l}\text { Black-and-white } \\
\text { Warbler }\end{array}$ & Mnv & 1 & 2 & 0.240 & 0.239 & G5 \\
\hline Myioborus miniatus & Slate-throated Redstart & Mym & 39 & 45 & 9.331 & 5.370 & G1 \\
\hline Myioborus ornatus & $\begin{array}{l}\text { Golden-fronted } \\
\text { Whitestart }\end{array}$ & Myo & 13 & 6 & 3.111 & 0.716 & G1 \\
\hline Myiothlypis coronate & $\begin{array}{l}\text { Russet-crowned } \\
\text { Warbler }\end{array}$ & Myc & 9 & 0 & 2.154 & 0 & G1 \\
\hline Setophaga fusca & Blackburn-ian Warbler & Sef & 20 & 49 & 4.785 & 5.848 & G1 \\
\hline Parkesia noveboracensis & Northern Waterthrush & Pan & 0 & 1 & 0 & 0.120 & G3 \\
\hline
\end{tabular}




\begin{tabular}{|c|c|c|c|c|c|c|c|}
\hline \multirow[t]{2}{*}{ Taxon name } & \multirow[t]{2}{*}{ English name } & \multirow[t]{2}{*}{ Code } & \multicolumn{2}{|c|}{ Absolute Abundance (AA) } & \multicolumn{2}{|c|}{ Relative abundance (RA\%) } & \multirow{2}{*}{$\begin{array}{c}\text { Functional } \\
\text { group }\end{array}$} \\
\hline & & & $\begin{array}{l}\text { Fragments of } \\
\text { Andean forest }\end{array}$ & $\begin{array}{l}\text { Wooded } \\
\text { pasture }\end{array}$ & $\begin{array}{l}\text { Fragments of } \\
\text { Andean forest }\end{array}$ & $\begin{array}{l}\text { Wooded } \\
\text { pasture }\end{array}$ & \\
\hline \multicolumn{8}{|l|}{ Fringillidae } \\
\hline Spinus psaltria & Lesser Goldfinch & Spp & 1 & 2 & 0.240 & 0.239 & G3 \\
\hline Spinus spinescens & Andean Siskin & Sps & 1 & 1 & 0.240 & 0.120 & G3 \\
\hline \multicolumn{8}{|l|}{ Virionidae } \\
\hline Vireo leucophrys & Brown-capped Vireo & Vil & 9 & 19 & 2.154 & 2.268 & G4 \\
\hline Vireo olivaceus & Red-eye Vireo & Vio & 0 & 2 & 0 & 0.239 & G3 \\
\hline \multicolumn{8}{|l|}{ Cardinalidae } \\
\hline Piranga rubra & Summer Tanager & Pir & 0 & 1 & 0 & 0.120 & G3 \\
\hline
\end{tabular}
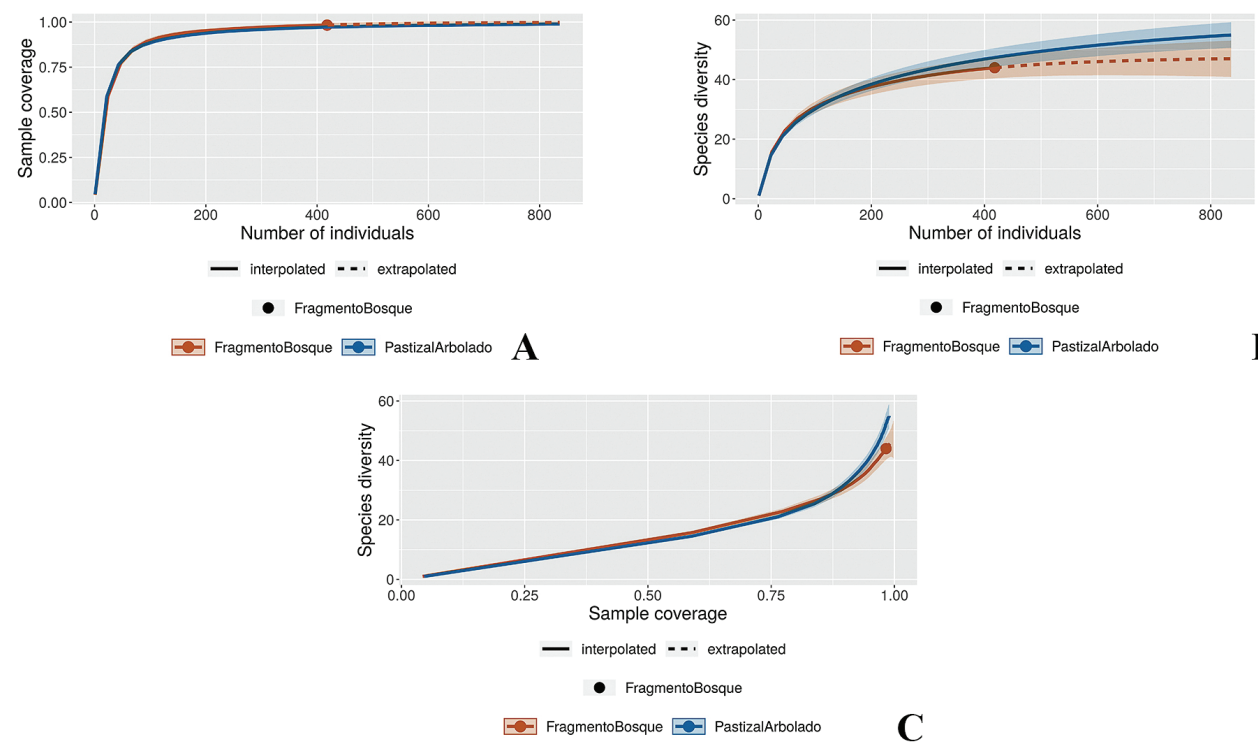

Figure 2. A Sampling coverage by number of bird individuals in a rural Andean landscape of the Eastern Cordillera of Colombia. Rarefaction (solid lines), and extrapolated (dotted lines). B Diversity of species by number of individuals in a rural Andean landscape of the Eastern Cordillera of Colombia. Interpolation (solid line) and extrapolation (dashed line). $\mathrm{C}$ Sampling coverage by number of bird species in a rural Andean landscape of the Eastern Cordillera of Colombia. Interpolation (solid line) and extrapolation (dashed line). The shadows on the curves correspond to the $95 \%$ confidence intervals.

(Table 1). In the Andean forest fragment, the relative abundance was 34\% (418), represented by seven unique individuals and seven species with two individuals (Table 1). The hierarchical distribution of the species abundance was different between the two vegetation covers (Fig. 3). For the wooded pasture, the species with the highest relative abundances were Atlapetes latinuchus, Turdus fuscater, Zonotrichia capensis, Atlapetes albofrenatus and Mecocerculus leucophrys and, for the Andean forest fragment, they were Myioborus miniatus, Atlapetes latinuchus, Coeligena prunellei, Atlapetes albofrenatus and Icterus chrysater. The species Atlapetes latinuchus and Atlapetes albofrenatus had high relative abundances in both plant cover types (Fig. 3). 


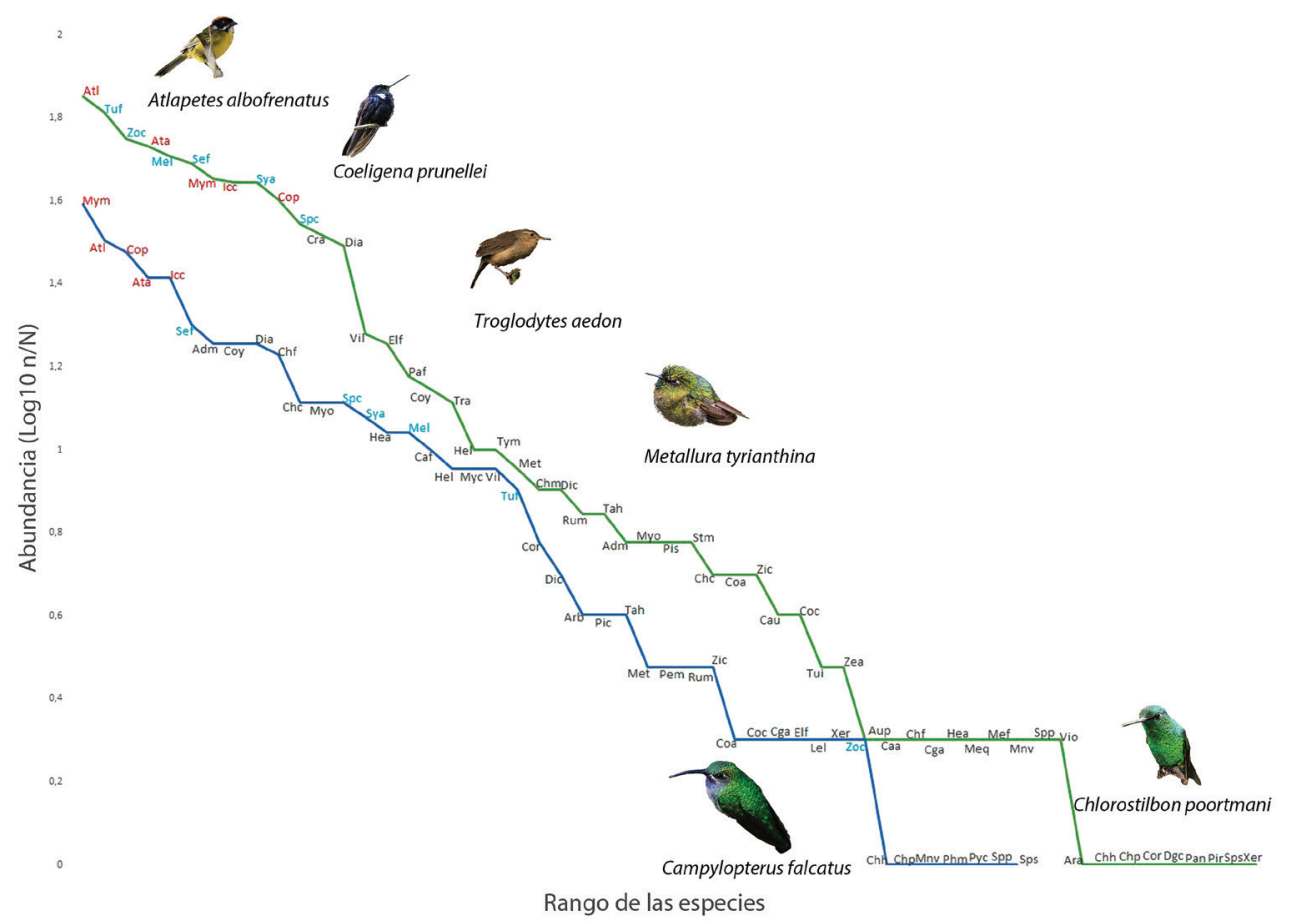

Figure 3. Range-abundance curve of the bird species for two covers evaluated in a rural landscape an Andean rural landscape of the Eastern Cordillera of Colombia. The green line corresponds to the cover of wooded grassland. Reference the codes in relation to Table 1.

The species that contributed the most to the dissimilarity between the vegetation covers were Zonotrichia capensis (SIMPER: 7.865\%), Turdus fuscater (SIMPER: 7.445\%), Mecocerculus leucophrys (SIMPER: 5.605\%) and Atlapetes latinuchus (SIMPER: 5.132\%), as well as species Crotophaga ani (SIMPER: 4.944\%), Synallaxis azarae (SIMPER: 4.788\%), Setophaga fusca (SIMPER: 4.627\%), Diglossa albilatera (SIMPER: 3.957\%) and Atlapetes albofrenatus (SIMPER: $3.935 \%)$.

\section{Beta diversity}

Of 63 species found, 19 were exclusive to the wooded grassland cover and eight were exclusive to the plant cover type of the Andean forest fragment (Table 1). The dissimilarity between the coverages was $43 \%$. The transects of each cover was also a high dissimilarity, $48 \%$ amongst the transects of the Andean forest fragment and $43 \%$ amongst those of the wooded pasture. We did not find differences between the richness and composition of the Andean forest fragment and the wooded pasture (ANOSIM: $\mathrm{R}=1, \mathrm{p}=0.32$ ). 
Table 2. Groups or functional types of birds in a rural Andean landscape of the Eastern Cordillera of Colombia. Each group was generated from cluster analysis for coverage type.

\begin{tabular}{|c|c|c|c|}
\hline Group & $\begin{array}{l}\text { Number } \\
\text { of species }\end{array}$ & Characteristics & Coverage \\
\hline G1 & 23 & $\begin{array}{l}\text { Mainly small, anisodactyl and pamprodactyl legged species, with diets based } \\
\text { mostly on insects, fruits and/or nectar. }\end{array}$ & $\begin{array}{l}\text { Fragment of Andean forest } \\
\text { and wooded pasture. }\end{array}$ \\
\hline G3 & 12 & $\begin{array}{l}\text { Species of small size, of trapping and foraging habits, with anisodactyl and } \\
\text { pamprodactyl legs, which can occupy the arboreal, shrubby and herbaceous } \\
\text { levels. }\end{array}$ & $\begin{array}{l}\text { Fragment of Andean forest } \\
\text { and wooded pasture. }\end{array}$ \\
\hline G4 & 8 & $\begin{array}{l}\text { Small and medium-sized species, which present anisodactyl legs, are mostly } \\
\text { catchers and scavengers, with straight beaks dominating, followed by hooked } \\
\text { ones. }\end{array}$ & $\begin{array}{l}\text { Fragment of Andean forest } \\
\text { and wooded pasture. }\end{array}$ \\
\hline G2 & 6 & $\begin{array}{l}\text { Species of small size, with anisodactyl legs, this group is dominated by species } \\
\text { with a not very specific diet, which includes fruits, seeds, insects and leaves, most } \\
\text { of the species in this group presented conical beaks. }\end{array}$ & $\begin{array}{l}\text { Fragment of Andean forest } \\
\text { and wooded pasture. }\end{array}$ \\
\hline G9 & 5 & $\begin{array}{l}\text { Large species, almost all of which occupy mainly the arboreal stratum, their diets } \\
\text { include the ingestion of carrion, meat and fruits. }\end{array}$ & $\begin{array}{l}\text { Fragment of Andean forest } \\
\text { and wooded pasture. }\end{array}$ \\
\hline G5 & 3 & $\begin{array}{l}\text { Small species, with insectivorous diet of curved beak, that occupy the shrub and } \\
\text { sapling levels. }\end{array}$ & $\begin{array}{l}\text { Fragment of Andean forest } \\
\text { and wooded pasture. }\end{array}$ \\
\hline G8 & 3 & $\begin{array}{l}\text { Medium-sized, curved-billed, zygodactyl, trappers or foragers, living in } \\
\text { monospecific and/or solitary flocks. }\end{array}$ & $\begin{array}{l}\text { Fragment of Andean forest } \\
\text { and wooded pasture. }\end{array}$ \\
\hline G7 & 2 & $\begin{array}{l}\text { Species of various sizes, of foraging habits, insectivorous, with zygodactyl legs, } \\
\text { with straight beaks, they mainly occupy the arboreal and shrub levels. }\end{array}$ & $\begin{array}{l}\text { Fragment of Andean forest } \\
\text { and wooded pasture. }\end{array}$ \\
\hline G6 & 1 & $\begin{array}{l}\text { A single, medium-sized, foraging species with zygodactyl legs and a high, } \\
\text { compressed beak that occupies the arboreal stratum and bases its diet on fruit } \\
\text { and insects. }\end{array}$ & Wooded pasture. \\
\hline
\end{tabular}

\section{Functional diversity}

We identified nine functional types: Group 1 (G1) was the best represented, made up of mainly small species, with anissodactyl and pamprodactyl legs and diets based on the ingestion of insects, fruits, nectar or both. Group 2 (G2) was represented by species of small size, trappers and foragers with anissodactyl and pamprodactyl legs that can occupy the shrub and herbaceous strata (Table 2). In the Andean forest fragment, we recorded eight of the nine groups identified in the entire study and, in the wooded pasture, all nine groups were represented. The functional equity (FEve) was 0.51 in the Andean forest fragment cover and differences are shown between the roles played by the dominant species (FDiv $=0.74$ ). In the wooded pasture, we obtained a lower functional equity (FEve $=0.45$ ) than in the Andean forest fragment. Similarly, role differentiation was presented by the dominant functional species (FDiv $=0.81$ ).

\section{Discussion}

\section{Taxonomic diversity of birds}

The diversity of birds in the rural landscape for each of their representative cover types was low in relation to other fragmented landscapes in Colombia, such as those found in the tropical and sub-Andean region of the Las Quinchas Mountain range 
in the Eastern Cordillera of Colombia (García-Monroy et al. 2020). Although the rural landscape of our study was completely in the Andean life region, for these sectors, there are records of a higher number of species (Córdoba-Córdoba and Echeverry-Galvis 2006; Jiménez 2010). In this regard, Trzcinski et al. (1999) hypothesise that the presence of bird species in the landscape is more related to the amount of habitat present than to the degree of fragmentation. Our rural landscape, despite being in areas bordering a protected area, has had a history of transformation in the last century, where most of the original coverage has diminished to critical points or has even disappeared (Etter 1993). This fact shows a configuration of the current landscape made up mostly of pastures for livestock, crops and small fragments of intervening forest, many of them the product of natural regeneration in the last four decades (Chavarro 2005).

The fact that, in the wooded pasture, the highest species richness value was recorded compared to the Andean forest fragment shows several ecological aspects of landscapes, as documented by Tabarelli et al. (2010), for fragmented landscapes of the Atlantic Forest. First, the greater heterogeneity of the wooded pastures gives rise to various areas that offer more resources, both for specialist species and generalists in choice of habitat. Second, the greatest amount of edge habitats are found for the wooded grasslands, facilitating edge effects: higher richness and higher detection values for the ecotonal area (e.g. for the study area the forest edges, areas around roads or living fences), as documented in multiple studies (GarcíaRomero et al. 2019). Third, the structure of vegetation in Andean forests with the presence of foreign species, such as Pinus radiata (Don, 1836) and Eucalyptus globulus (Labill, 1800), limits food resources and nesting sites for many bird species (Zurita et al. 2006); and this is directly related to the alpha diversity for these plant cover types.

Another ecological aspect that has a direct effect on the species richness values in the sample cover types and that is often not considered because of inferences towards a specific taxonomic group is the detection capacity. This can be managed with other methodologies. However, for the purpose of this study and that of observing the functional attributes, direct observation of the species was necessary. This fact together with the fact that the wooded grassland area had more heterogeneity than the Andean forest fragment and given the complex plant structure and homogeneous nature of the latter, the type of plant cover limited observations, while they were facilitated in areas of wooded grasslands with open areas (Enríquez-Lenis et al. 2007).

In terms of composition and structure, the differences recorded between the plant cover types are due, like the species richness, to the structural complexity in terms of the vegetation of each of the plant cover type. This is a general pattern identified in rural landscapes (Cook et al. 2002). In contrast, the conjunction of remnant vegetation, living fences and production areas with isolated trees in wooded pastures creates suitable locations for the establishment and occupation of sites corresponding to species with a wide spectrum of habitat, generalists in the choice of resources, such as Turdus fuscater, Zonotrichia capensis and Tyrannus melancholicus 
(Ocampo-Peñuela and Pimm 2015). In the case of the Andean forest fragment, the assemblage has generalist species, but also there are others with some degree of specialisation, for example, Pyrrhomyias cinnamomeus and Colaptes rivolii (Avendaño et al. 2013). This is a pattern like that recorded in other fragmented natural systems (Zurita et al. 2006; Tabarelli et al. 2010; Hadley et al. 2018).

The contrasting plant cover in the landscape contributes to the turnover of species within the types of cover observed in the wooded pasture, as it is the dominant cover in the north-eastern Andean landscapes after grasslands (Etter 1998). In this way, wooded grasslands serve as a transition zone between the open areas and the Andean forest fragment. However, it is important to bear in mind that both plant covers have a different structure and contribute unique species to the assemblage of birds in the landscape. This is a basic input when taking conservation actions in this type of region since this contrast of areas contributes greatly to the maintenance of biodiversity in these transformed landscapes (Lôbo et al. 2011).

The exchange of species found in the study area can be linked to the heterogeneity that is present in tropical landscapes altered by changes in land use. The landuse changes directly affect the composition of birds within the landscape vegetation coverage; and according to the spatial scale of the analysis, it can generate variations within the analysed coverage, together with other filters and biotic variables of each landscape (Morante-Filho et al. 2016).

\section{Functional diversity}

From the results, we observe that there is higher functional diversity in the wooded pasture with respect to the Andean forest cover. There is also a marked relationship between functional equity and the distribution of wealth between functional attributes (Luck et al. 2013). However, the fact that functional diversity does not decrease with the degree of simplification of the structure of the plant cover reflects a result that is observed infrequently in fragmented landscapes, when the biodiversity values are congruent with the complexity of the structure of the vegetation that is evaluated. It also provides information on the response of the assemblages to these new landscapes, where the greater heterogeneity of the wooded landscapes could provide a greater number of resources for the maintenance of the bird assemblage and the history of disturbances of the fragments clearly reflects the composition and structure of current assemblages. In this way, the fragments of secondary forests that form the rural landscapes of the north-eastern Andes of Colombia are the product of regeneration, restoration or both during the last three decades, where the vegetation has reached structural maturity, but perhaps the faunal groups that occupy these areas do not follow the same maturity line (Etter 1993). This fact represents a priority topic for evaluation in this type of rural landscape.

Regarding functional divergence, the values obtained for the two vegetation types reflect high niche differentiation, allowing better use of the resources that the plant cover type provides and reduces the levels of competition (Ding et al. 2017). 
In addition to this, we found a higher abundance of frugivorous and nectarivorous birds in the plant cover of the wooded grasslands. These species may be closely related to the passive restoration of the site since they influence pollination and seed dispersal, like that documented by Tscharntke et al. (2012). In addition, the absence of group G6 in the Andean forest fragment cover, represented only by Aulacorhynchus prasinus (Gould, 1833) in wooded pasture, may be attributed to the scarcity of fruits in the forest. This scarcity of food could generate a differential effect on the distribution of the functional attributes and, therefore, a functional contrast between the coverages.

\section{Implications for landscape management and bird conservation}

Although the wooded pasture presented a better state at a taxonomic and functional level, it is important to maintain the remnants of Andean forests, since they contribute to the functional richness of the area, in general and to an increase in the diversity of a landscape with contrasting hedges. The heterogeneity of the landscape generated a differential effect on the patterns of species richness and also on the patterns of species turnover and positively affected birds, along with the effect of a system that included semi-natural habitats, low-intensity agriculture and various mosaics of small-scale land-use types.

The contrast of cover allowed the birds' greater mobility with fewer interruptions within the landscape since bird assemblages tended to avoid clearly-defined forest edges and completely open areas. A strategy for the study area is the enrichment of living fences and wooded pastures that, due to their high heterogeneity, provide good resource availability for birds in the rural landscape.

\section{Acknowledgements}

Roberto Chavarro Chavarro, owner of the Natural Reserve of the Civil Society "Rogitama Biodiversidad", partially financed this research and provided logistical support for the mobilisation between the different sampling coverages. The Biodiversity and Conservation research group of the Pedagogical and Technological University of Colombia provided tutorials for the statistical analyses of this research. This article is published as a product of the Project "The biodiversity of Boyacá: Complementation and synthesis through altitudinal gradients and implementations of its incorporation in projects of social appropriation of knowledge and the effects of climate change, Boyacá" BPIN 2020000100003.

\section{References}

Avendaño JE, Cortés-Herrera JO, Briceño-Lara ER, Rincón-Guarín DA (2013) Crossing or bypassing the Andes: A commentary on recent range extensions of cis-Andean birds to the west of the Andes of Colombia. Orinoquia (Universidad Tecnologica de los Llanos Orientales) 17(2): 207-214. https://doi.org/10.22579/20112629.18 
Bilenca DN, Abba AM, Corriale MJ, Carusi LCP, Pedelacq ME, Zufiaurre E (2017) De venados, armadillos y coipos: Los mamíferos autóctonos frente a los cambios en el uso del suelo, los manejos agropecuarios y la presencia de nuevos elementos en el paisaje rural. Mastozoología Neotropical 24(2): 277-287.

Cadotte MW, Carscadden K, Mirotchnick N (2011) Beyond species: Functional diversity and the maintenance of ecological processes and services. Journal of Applied Ecology 48(5): 1079-1087. https://doi.org/10.1111/j.1365-2664.2011.02048.x

Carvajal-Castro JD, Ospina-L AM, Toro-López Y, Pulido-G A, Cabrera-Casas LX, Guerrero-Peláez S, Vargas-Salinas F (2019) Birds vs. bricks: Patterns of species diversity in response to urbanization in a Neotropical Andean city. PLoS ONE 14(6): e0218775. https://doi.org/10.1371/journal.pone.0218775

Casanoves F, Pla L, Di Rienzo JA, Díaz S (2011) FDiversity: A software package for the integrated analysis of functional diversity. Methods in Ecology and Evolution 2(3): 233237. https://doi.org/10.1111/j.2041-210X.2010.00082.x

Cavelier J, Etter A (1995) Deforestation of montane forests in Colombia as a result of illegal plantations of opium (Papaver somniferum). In: Churchill SP, Balslev H, Forero E, Luteyn JL (Eds) Biodiversity and Conservation of Neotropical Montane Forests, Proceedings of the Neotropical Montane Forest Biodiversity and Conservation Symposium, The New York Botanical Garden, 21-26 june 1993, 541-550.

Chao A, Jost L (2012) Coverage-based rarefaction and extrapolation: Standardizing samples by completeness rather than size. Ecology 93(12): 2533-2547. https://doi. org/10.1890/11-1952.1

Chao MT, Lo SH (1994) Maximum likelihood summary and the bootstrap method in structured finite populations. Statistica Sinica: 389-406.

Chao A, Gotelli NJ, Hsieh TC, Sander EL, Ma KH, Colwell RK, Ellison AM (2014) Rarefaction and extrapolation with Hill numbers: A framework for sampling and estimation in species diversity studies. Ecological Monographs 84(1): 45-67. https://doi.org/10.1890/13-0133.1

Chavarro R (2005) Ilustraciones y fotografías de aves-Coeligena prunellei Inca Negro-Black Inca (Príncipe de Arcabuco). Boletín SAO 15(2): 118-122.

Clarke KR (1993) Non-parametric multivariate analyses of changes in community structure. Australian Journal of Ecology 18(1): 117-143. https://doi.org/10.1111/j.1442-9993.1993. tb00438.x

Collinge SK (2009) Ecology of fragmented landscapes. Johns Hopkins University Press, Baltimore, $341 \mathrm{pp}$.

Colwell RK, Coddington JA (1994) Estimating terrestrial biodiversity through extrapolation. Philosophical Transactions of the Royal Society of London - Series B, Biological Sciences 345(1311): 101-118. https://doi.org/10.1098/rstb.1994.0091

Colwell RK, Chao A, Gotelli NJ, Lin S-Y, Mao CX, Chazdon RL, Longino JT (2019) Models and estimators linking individual-based and sample-based rarefaction, extrapolation, and comparison of assemblages. Journal of Plant Ecology 5(1): 3-21. https://doi. org/10.1093/jpe/rtr044

Cook WM, Lane KT, Foster BL, Holt RD (2002) Island theory, matrix effects and species richness patterns in habitat fragments. Ecology Letters 5(5): 619-623. https://doi. $\operatorname{org} / 10.1046 /$ j.1461-0248.2002.00366.x 
Córdoba-Córdoba S, Echeverry-Galvis MÁ (2006) Diversidad de aves de los bosques mixtos y de roble del Santuario de Flora y Fauna de Iguaque, Boyacá. I Simposio Internacional de Roble y Ecosistemas Asociados, Memorias, 119-128.

Daily GC, Ehrlich PR, Sánchez-Azofeifa GA (2001) Countryside biogeography: use of human-dominated habitats by the avifauna of southern Costa Rica. Ecological applications 11(1): 1-13. https://doi.org/10.1890/1051-0761(2001)011[0001:CBUOHD]2.0.CO;2

Di Rienzo JA, InfoStat versión (2009) Grupo InfoStat, FCA, Universidad Nacional de Córdoba, Argentina. http://www.infostat.com.ar

Ding N, Weifang Y, Zhou Y, González-Bergonzoni I, Zhang J, Chen K, Vidal N, Jeppesen E, Liu Z, Wang B (2017) Different responses of functional traits and diversity of stream macroinvertebrates to environmental and spatial factors in the Xishuangbanna watershed of the upper Mekong River Basin, China. The Science of the Total Environment 574: 288-299. https://doi.org/10.1016/j.scitotenv.2016.09.053

Enríquez-Lenis ML, Sáenz JC, Ibrahim M (2007) Richness, abundance and diversity of birds and their relationship with tree cover in an agricultural landscape dominated by cattle in the sub-humid tropics of Costa Rica. Agroforestería en las Américas 45: 49-57. [CATIE]

Etter A (1993) Diversidad ecosistémica en Colombia hoy. Nuestra Diversidad Biológica, $43-61$.

Etter A (1998) Bosque húmedo tropical. Informe nacional sobre el estado de la diversidad. Instituto de Investigación de Recursos Biológicos Alexander von Humboldt, PNUMA, Ministerio del Medio Ambiente. Bogotá, Colombia, 106-133.

Freedman B (2014) Population growth and global change. Global environmental change. Springer, Berlin, 571-577. https://doi.org/10.1007/978-94-007-5784-4_39

Gale GA, Round PD, Pierce AJ, Nimnuan S, Pattanavibool A, Brockelman WY (2009) A field test of distance sampling methods for a tropical forest bird community. The Auk 126(2): 439-448. https://doi.org/10.1525/auk.2009.08087

Galindo R (2000) Esquema de Ordenamiento Territorial del Municipio de Arcabuco-Boyacá. Planificación económica, social, dimensión territorial y aprovechamiento sostenible (Ley 388 de 1997). Gobierno municipal de Arcabuco, Boyacá, Colombia, 321 pp.

García-Monroy JS, Morales-González ÓE, Carvajal-Cogollo JE (2020) New bird records for the Serranía de Las Quinchas, Colombia: Inventory update and comments on distributions in an altitudinal gradient. Check List 16(6): 1475-1518. https://doi. org/10.15560/16.6.1475

García-Romero A, Vergara PM, Granados-Peláez C, Santibañez-Andrade G (2019) Landscape-mediated edge effect in temperate deciduous forest: Implications for oak regeneration. Landscape Ecology 34(1): 51-62. https://doi.org/10.1007/s10980-018-0733-x

Hadley AS, Frey SJ, Robinson WD, Betts MG (2018) Forest fragmentation and loss reduce richness, availability, and specialization in tropical hummingbird communities. Biotropica 50(1): 74-83. https://doi.org/10.1111/btp.12487

Herrel A, Podos J, Huber SK, Hendry AP (2005) Bite performance and morphology in a population of Darwin's finches: Implications for the evolution of beak shape. Functional Ecology 19(1): 43-48. https://doi.org/10.1111/j.0269-8463.2005.00923.x 
Howe RW, Niemi GJ, Lewis SJ, Welsh DA (1997) A standard method for monitoring songbird populations in the Great Lakes region. The Passenger Pigeon 59(3): 183-194.

Hsieh TC, Ma KH, Chao A (2013) iNEXT online: interpolation and extrapolation (Version 1.0)[Software]. http://chao.stat.nthu.edu.tw/blog/software-download

Ikin K, Yong DL, Lindenmayer DB (2016) Effectiveness of woodland birds as taxonomic surrogates in conservation planning for biodiversity on farms. Biological Conservation 204: 411-416. https://doi.org/10.1016/j.biocon.2016.11.010

IPBES (2019) Summary for policymakers of the global assessment report on biodiversity and ecosystem services of the Intergovernmental Science-Policy Platform on Biodiversity and Ecosystem Services. IPBES Secretariat, Bonn, Germany, 56 pp.

Issa MAA (2019) Diversity and abundance of wild birds species' in two different habitats at Sharkia Governorate, Egypt. Journal of Basic \& Applied Zoology 80(1): e34. https://doi. org/10.1186/s41936-019-0103-5

Jiménez FAS (2010) Aproximación a la fauna asociada a los bosques de roble del Corredor Guantiva-La Rusia-Iguaque (Boyacá-Santander, Colombia). Colombia Forestal 13(2): 299-334. https://doi.org/10.14483/udistrital.jour.colomb.for.2010.2.a08

Laliberté E, Legendre P (2010) A distance-based framework for measuring functional diversity from multiple traits. Ecology 91(1): 299-305. https://doi.org/10.1890/08-2244.1

Lampila P, Mönkkönen M, Desrochers A (2005) Demographic responses by birds to forest fragmentation. Conservation Biology 19(5): 1537-1546. https://doi.org/10.1111/j.15231739.2005.00201.x

Larsen FW, Bladt J, Balmford A, Rahbek C (2012) Birds as biodiversity surrogates: Will supplementing birds with other taxa improve effectiveness? Journal of Applied Ecology 49(2): 349-356. https://doi.org/10.1111/j.1365-2664.2011.02094.x

Lawton JH, Bignell DE, Bolton B, Bloemers GF, Eggleton P, Hammond PM, Hodda M, Holt RD, Larsen TB, Mawdsley NA, Stork NE, Srivastava DS, Watt AD (1998) Biodiversity inventories, indicator taxa and effects of habitat modification in tropical forest. Nature 391(6662): 72-76. https://doi.org/10.1038/34166

Leach EC, Burwell CJ, Ashton LA, Jones DN, Kitching RL (2016) Comparison of point counts and automated acoustic monitoring: Detecting birds in a rainforest biodiversity survey. The Emu 116(3): 305-309. https://doi.org/10.1071/MU15097

Lôbo D, Leão T, Melo FP, Santos AM, Tabarelli M (2011) Forest fragmentation drives Atlantic Forest of northeastern Brazil to biotic homogenization. Diversity \& Distributions 17(2): 287-296. https://doi.org/10.1111/j.1472-4642.2010.00739.x

López-Ordoñez JP, Stiles FG, Parra-Vergara JL (2015) Protocolo para la medición de rasgos funcionales en aves. In: Salgado-Negret B (Ed.) La ecología funcional como aproximación al estudio, manejo y conservación de la biodiversidad: protocolos y aplicaciones. Instituto de Investigación de Recursos Biológicos Alexander von Humboldt. Bogotá, D. C. Colombia, 80-126.

Luck GW, Carter A, Smallbone L (2013) Changes in bird functional diversity across multiple land uses: Interpretations of functional redundancy depend on functional group identity. PLoS ONE 8(5): e63671. https://doi.org/10.1371/journal.pone.0063671 
McMullan M, Donegan TM (2014) Field Guide to the Birds of Colombia, $2^{\text {nd }}$ edn. Fundación ProAves, Bogotá.

Morante-Filho JC, Arroyo-Rodríguez V, Faria D (2016) Patterns and predictors of $\beta$ diversity in the fragmented Brazilian Atlantic Forest: A multiscale analysis of forest specialist and generalist birds. Journal of Animal Ecology 85(1): 240-250. https://doi. org/10.1111/1365-2656.12448

Mouillot D, Mason WH, Dumay O, Wilson JB (2005) Functional regularity: a neglected aspect of functional diversity. Oecologia 142(3): 353-359. https://doi.org/10.1007/ s00442-004-1744-7

Newbold T, Scharlemann JP, Butchart SH, Şekercioğlu ÇH, Alkemade R, Booth H, Purves DW (2013) Ecological traits affect the response of tropical forest bird species to land-use intensity. Proceedings of the Royal Society B: Biological Sciences 280(1750): 2012-2131. https://doi.org/10.1098/rspb.2012.2131

Ocampo-Peñuela N, Pimm SL (2015) Elevational ranges of montane birds and deforestation in the Western Andes of Colombia. PLoS ONE 10(12): e0143311. https://doi. org/10.1371/journal.pone.0143311

Oldeland J, Wesuls D, Rocchini D, Schmidt M, Jürgens N (2010) Does using species abundance data improve estimates of species diversity from remotely sensed spectral heterogeneity? Ecology 10: 390-396. https://doi.org/10.1016/j.ecolind.2009.07.012

Petchey OL, Gaston KJ (2002) Functional diversity (FD), species richness and community composition. Ecology Letters 5(3): 402-411. https://doi.org/10.1046/j.14610248.2002.00339.x

Pettingill OS (1985) Ornithology in Laboratory and Field. $5^{\text {th }}$ edn. Academic Press, London, 409 pp.

Ralph CJ, Geupel GR, Pyle P, Martin TE, DeSante DF, Milá B (1996) Manual de métodos de campo para el monitoreo de aves terrestres. Gen. Tech. Rep. PSW-GTR-159. Albany, CA: US Department of Agriculture, Forest Service, Pacific Southwest Research Station, 159 pp. https://doi.org/10.2737/PSW-GTR-159

Ranganathan J, Daily GC (2008) La biogeografía del paisaje rural: oportunidades. Evaluación y conservación de biodiversidad en paisajes fragmentados de Mesoamérica, 15 pp.

Rangel-Ch JO, Lozano-C G (1986) Un perfil de vegetación entre La Plata (Huila) y el volcán del Puracé. Caldasia: 503-547.

Rangel-Ch JO, Lowy-C PD, Aguilar-P M, Garzón-C A (1997) Tipos de vegetación en Colombia. Una aproximación al conocimiento de la terminología fitosociológica, fitoecológica y de uso común. In: Rangel-Ch JO, Lowy-C P, Aguilar-P M (Eds) Diversidad Biótica II. Tipos de Vegetación en Colombia. Universidad Nacional de Colombia-Instituto de Ciencias Naturales, Instituto de hidrología, Meteorología y estudios Ambientales (IDEAM)-Ministerio del Medio Ambiente, Comité de Investigaciones y Desarrollo Científico-CINDEC.U.N, Academia Colombiana de Ciencias Exactas, Físicas y Naturales. Bogotá, 304-382.

Remsen JV, Areta JI, Bonaccorso E, Claramunt S, Jaramillo A, Pacheco JF, Robbins MB, Stiles FG, Stotz DF, Zimmer KJ (2020) A classification of the bird species of South 
America. American Ornithological Society Version [2020]. http://www.museum.lsu. edu/ Remsen/SACCBaseline.htm

Restall RL, Rodner C, Lentino M (2007) Birds of Northern South America: Plates and maps (Vol. 2). Yale University Press, 880 pp.

Ridgely RS, Tudor G (2009) Field Guide to the songbirds of South America: the passerines. University of Texas Press, 748 pp.

Sekercioglu CH (2006) Increasing awareness of avian ecological function. Trends in Ecology \& Evolution 21(8): 464-471. https://doi.org/10.1016/j.tree.2006.05.007

Stotz DF, Fitzpatrick JW, Parker TA, Moskovits DK (1996) Neotropical birds: ecology and conservation. University of Chicago Press, 293-377.

Tabarelli M, Aguiar AV, Ribeiro MC, Metzger JP, Peres CA (2010) Prospects for biodiversity conservation in the Atlantic Forest: Lessons from aging human-modified landscapes. Biological Conservation 143(10): 2328-2340. https://doi.org/10.1016/j.biocon.2010.02.005

Trzcinski MK, Fahrig L, Merriam G (1999) Independent effects of forest cover and fragmentation on the distribution of forest breeding birds. Ecological Applications 9(2): 586-593. https://doi.org/10.1890/1051-0761(1999)009[0586:IEOFCA]2.0.CO;2

Tscharntke T, Tylianakis JM, Rand TA, Didham RK, Fahrig L, Batary P, Bengtsson J, Clough Y, Crist TO, Dormann CF, Ewers RM, Fründ J, Holt RD, Holzschuh A, Klein AM, Kleijn D, Kremen C, Landis DA, Laurance W, Lindenmayer D, Scherber C, Sodhi N, Steffan-Dewenter I, Thies C, van der Putten WH, Westphal C (2012) Landscape moderation of biodiversity patterns and processes-eight hypotheses. Biological Reviews of the Cambridge Philosophical Society 87(3): 661-685. https://doi.org/10.1111/j.1469185X.2011.00216.x

Veríssimo D, Fraser I, Groombridge J, Bristol R, MacMillan DC (2009) Birds as tourism flagship species: A case study of tropical islands. Animal Conservation 12(6): 549-558. https://doi.org/10.1111/j.1469-1795.2009.00282.x

Villard MA, Trzcinski MK, Merriam G (1999) Fragmentation effects on forest birds: Relative influence of woodland cover and configuration on landscape occupancy. Conservation Biology 13(4): 774-783. https://doi.org/10.1046/j.1523-1739.1999.98059.x

Villéger S, Mason NWH, Mouillot D (2008) New multidimensional functional diversity indices for a multifaceted framework in functional ecology. Ecology 89(8): 2290-2301. https://doi.org/10.1890/07-1206.1

Westgate MJ, Barton PS, Lane PW, Lindenmayer DB (2014) Global meta-analysis reveals low consistency of biodiversity congruence relationships. Nature Communications 5(1): 1-8. https://doi.org/10.1038/ncomms4899

Wilman H, Belmaker J, Simpson J, de la Rosa C, Rivadeneira MM, Jetz W (2014) EltonTraits 1.0: Species-level foraging attributes of the world's birds and mammals: Ecological Archives E095-178. Ecology 95(7): 2027-2027. https://doi.org/10.1890/13-1917.1

Zurita GA, Rey N, Varela DM, Villagra M, Bellocq MI (2006) Conversion of the Atlantic Forest into native and exotic tree plantations: Effects on bird communities from the local and regional perspectives. Forest Ecology and Management 235(1-3): 164-173. https://doi.org/10.1016/j.foreco.2006.08.009 